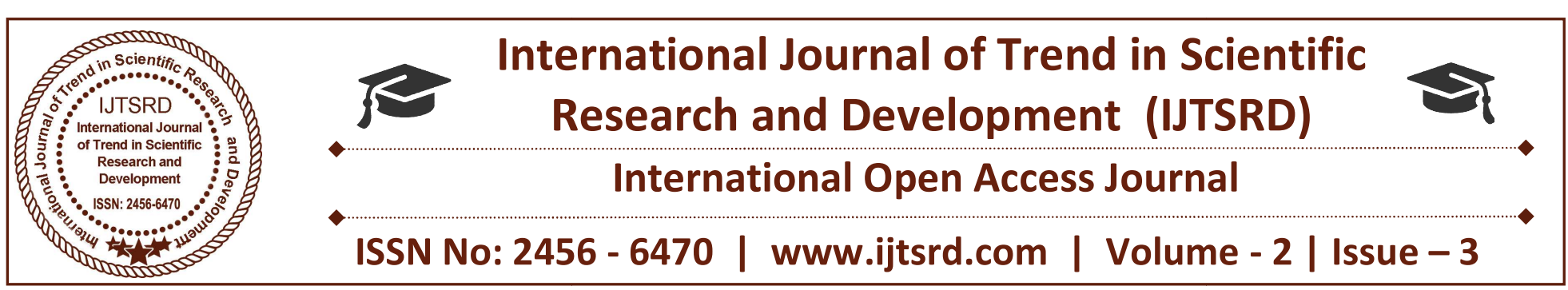

\title{
Studies on Earthworm Population and Diversity with Special Reference to Physicochemical Parameters in Two Different Habitats
}

\author{
R. Devi, Serfoji. P.* \\ Post Graduate and Research Department of Zoology, Government Arts College (Autonomous), \\ Kumbakonam, Tamil Nadu, India
}

\begin{abstract}
Biodiversity is vital to several important ecosystem services that ensure sustainability of food production. In organic agriculture, land management practices that promote biodiversity and soil quality are emphasized and the goal is to maintain a sustainable agriculture system. Earthworms are major components of the soil fauna in a wide variety of soils and climates are involved directly or indirectly in biodegradation, stabilization through humus formation, and various soil processes. Earthworm are important components of agro ecosystem soils, since they contribute to soil physical- chemical properties and processes, and can substantially modify the biodiversity and function of soil communities.
\end{abstract}

\section{Keywords: Biodiversity, Communities, Biodegradation, Fragmentation}

\section{INTRODUCTION}

Earthworms are terrestrial invertebrates belonging to the Phylum Annelida, Class Chaetopoda, Order Oligochaeta, which have originated about 600 million years ago, during the pre-Cambrian era (Piearce et al., 1990). Earthworms occur in diverse habitat, exhibiting effective activity, by bringing about physical and chemical changes in the soil leading to improvement in soil fertility and approach towards good soil management, with an emphasis on the role of soil dwellers like earthworms, in soil fertility, is very important in maintaining balance in an ecosystem (Shuster et al., 2000). They are biological indicators of soil quality (Ismail, 2005), as a good population of earthworms indicates the presence of a large population of bacteria, viruses, fungi, insects, spiders and other organisms and thus a healthy soil (Lachnicht and Hendrix, 2001).

Earthworms restore and improve soil fertility and boost crop productivity by the use of their excretory products -'vermicast'. They excrete beneficial soil microbes, and secrete polysaccharides, proteins and other nitrogenous compounds into the soil. They promote soil fragmentation and aeration, and bring about 'soil turning' and dispersion in farmlands. Worm activity can increase air-soil volume from 8$30 \%$. One acre of land can contain up to 3 million earthworms the activities of which can bring up to 810 tons of 'top soil' to the surface (in the form of vermicast) every year. Presence of worms regenerate compacted soils and improves water penetration in such soils by over $50 \%$. (Bhat and Khambata, 1996). U.S. study indicate that 10,000 worms in a farm plot provides the same benefit as three farmers working 8 hours in shift all year round with 10 tons of manure applied in the plot (Li, 2005).

Earthworms are natural invertebrates of agro ecosystem belonging to the family lumbricidae and dominant in the temperate and tropical soils. They are hermaphrodites, both male and female reproductive organs are present in every single earthworm but self-fertilization does not generally occur. At the time of laying eggs, the sexually mature worms have a distinctive epidermal ring shaped area called, the clitellum, which has gland cells that 
secrete material to form a viscid, girdle like structure known as cocoon. Cocoons are small, with their size varying according to species. The colour of the cocoon changes gradually as it develops from the freshly laid stage to the hatching stage. Though the number of fertilized ova in each cocoon ranges from one to twenty for lumbricid worms (Stephenson, 1930), often only one or two survive and hatch (Edward, 1967).

Earthworms are generally classified into epigeic, endogeic, and anecic depending upon different lifestyles (Bouche, 1977). Epigeic worms live in soil surface of 3-10 cm and feed on leaf litter. Endogeic worms live deep in the soil from $10-30 \mathrm{~cm}$ and feed on the humic materials and mineral matter, where as anecic worms can go very deep into soil upto 60-90 $\mathrm{cm}$ and feed on the humic materials and mineral matter are available approximately 3600 kinds of earthworms are found in the world and are represented from every soil type of the globe (Verma and Prasad, 2005).

\section{Material and Methods}

\section{Collection of Sample - Station I}

The Thiruppampuram village are located in Thiruvarur district, Tamilnadu, India. The total geographical area of the village is 220 hectares, the percentage of cultivable area are 160 hectares and respectively. This shows that Thiruppampuram is predominantly an agricultural area. Agriculture is the most important economic activity in the Thiruvarur district, both in terms of employment and output.

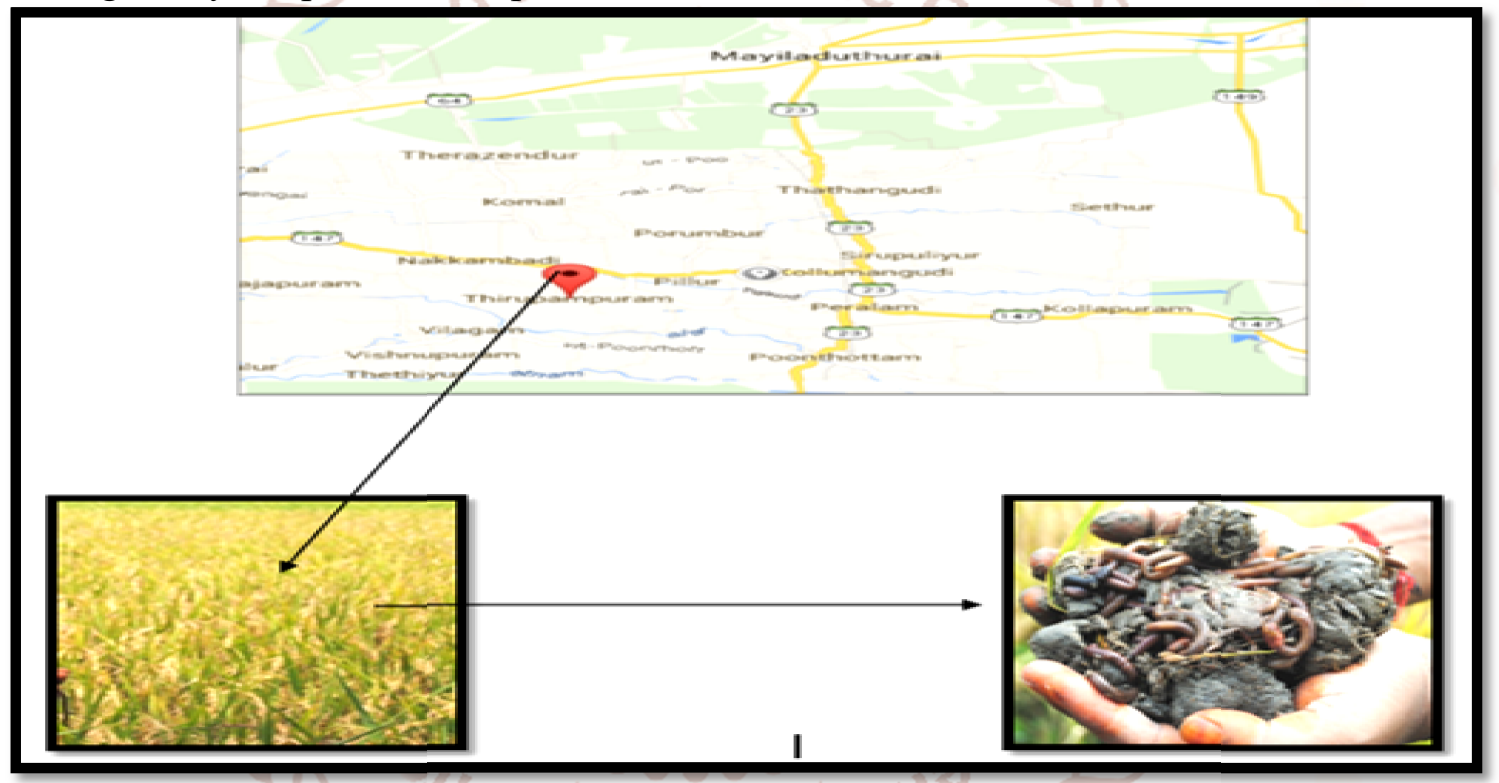

Figure 1 Study Area (Station - I)

\section{Station -II}

The study area located at kumbakonam, It is an industrial and Residential area. It is a waste dumping site used by the kumbakonam city council and environmental mainly domestic and household waste. Kumbakonam is a municipal and second largest town in Thanjavur District, Tamilnadu. 


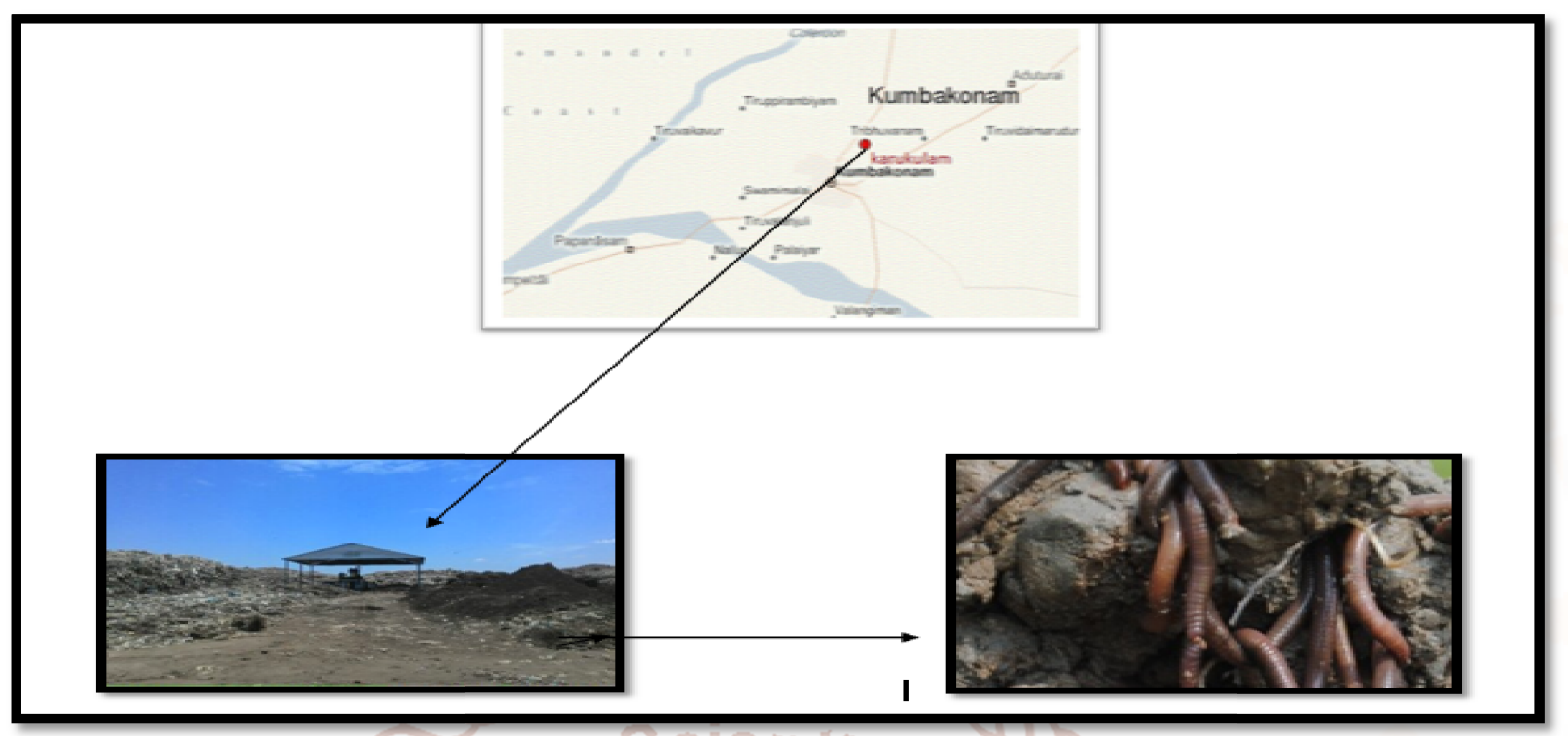

Figure 2 Study Area (Station - II)

The earthworms were collected from two different sites in paddy field Thiruppampuram village and municipal solid waste dumping site at Kurikulam, Kumbakonam. Earthworms for the taxonomic studies were collected and hand-sorted as per the techniques of Edwards and Lofty (1977). Collected worms were washed in fresh water. The earthworms and soil were stored in perforated polythene bags and were brought to the laboratory for their identification.

The alive worms were placed in an enameled tray half-filled with water, narcotized by gradually adding ethanol to the water. When the worms became motionless and did not respond to probing, they were fixed for 12 hours in straightened position in another enameled tray containing $10 \%$ formalin. The fixed specimens were preserved in $5 \%$ fresh formalin in suitable glass vials. Relaxed and straightened worms were taken for dissection to study their external and internal morphological characteristics. A label indicating collection locality with region and season accompanied in each lot of preserved worms. All preserved specimens examined and reported in the present work are deposited our Research Institute for further reference and study.

\section{Identification of Earthworm}

\section{i. External Study}

To study the number of metameres, setae and their attachment pattern, pro and peristomium, position of clitellum, dorsal pores, spermathecal apertures, male and female genital apertures/markings and dorsal and ventral blood vessels magnifying glass and dissecting microscope were assessed.

\section{ii. Internal study}

It was carried out by dissecting worms longitudinally, slightly left to right side of the middorsal line with a sharp shaving blade. Location of internal organs (pharynx, gizzard, last pair of heart, intestine and position of testis, ovaries, prostatic glands and calciferous glands etc.), their presence or absence and morphology were studied and recorded. Identification of earthworm species was confirmed by the taxonomic and monographic work of (Stephenson, 1923; Julka and Senapati, 1987; Julka, 1988, 2001; Julka and Paliwal, 1994, Prakash, 2011). On the basis of external and internal morphological characters, four genera with species of earthworms from three Oligochaeta families were identified Lampito mauritii (Kinberg, 1866), and Perionyx excavatus (Perreir, 1872) from Megascolecidae family; Eudrilus eugeniae, (Kinberg,1866) Eisenia foetida (Savingny 1926) were identified from paddy soil sites. Lampito maruitii, Perionyx excavates was the dominant species of paddy field and dumping site areas. 


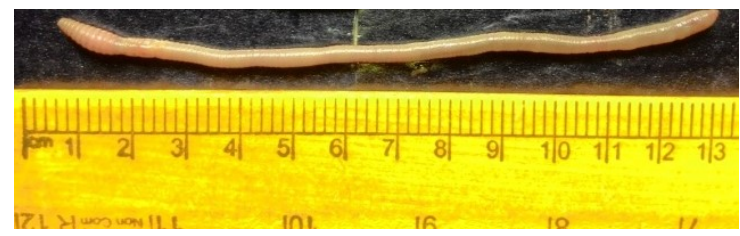

Eudrilus eugeniae

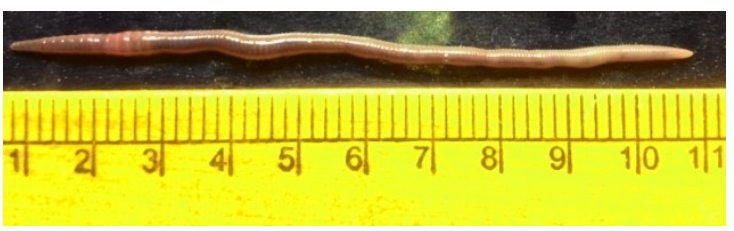

Eisenia foetida

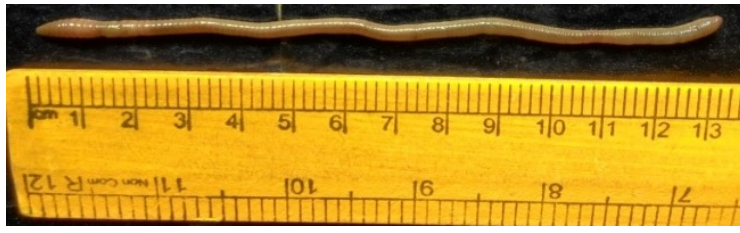

Perionyx excavates

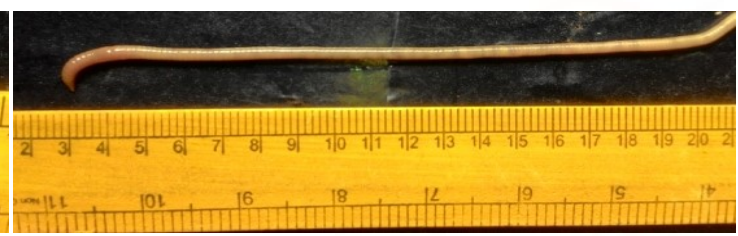

Lampito maruitii

Figure 3 Types of earthworms in paddy field

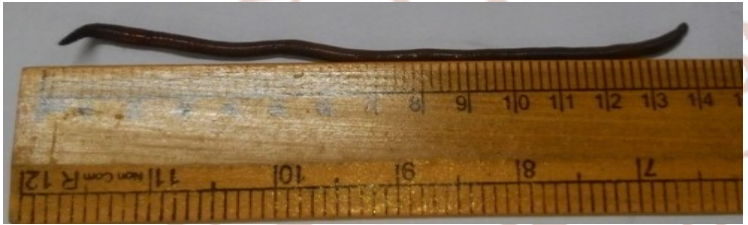

Perionyx excavates

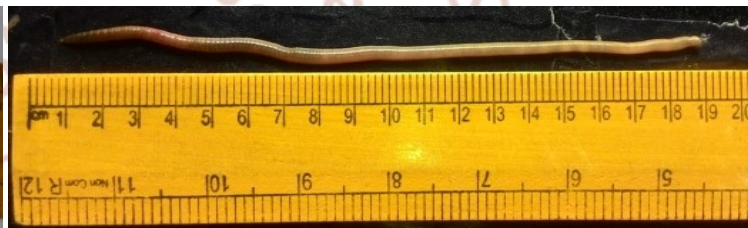

Lampito maruitii

Figure 4 Types of earthworms in Dumping site

Table 1. Earthworm population in two different habitats

\begin{tabular}{|l|r|c|c|c|}
\hline \multirow{2}{*}{ Habitat } & \multicolumn{2}{|c|}{ Name of the Species } \\
\cline { 2 - 5 } & $\begin{array}{c}\text { Lampito } \\
\text { maruitii }\end{array}$ & Perionyx excavates & Eudrillus eugeniae & Eisenia foetida \\
\hline 1. Paddy field & 16 & 18 & 11 & 09 \\
\hline 2. Dumping site field & 08 & 07 & 02 & 03 \\
\hline
\end{tabular}

Table1. Present study of general characters in various earthworms

\begin{tabular}{|c|c|c|c|c|}
\hline Species & Lampito maruitii & Eisenia foetida & Eudrilus eugeniae & Perionyx excavates \\
\hline Habitat's & Anecic & Epigeic (Exotic) & Epigeic (Exotic) & Epigeic \\
\hline $\begin{array}{l}\text { Common } \\
\text { name }\end{array}$ & Night crawlers & Red worm & $\begin{array}{l}\text { African knight } \\
\text { crawler }\end{array}$ & Indian Blue worm \\
\hline Native & India & Europe & Africa & India \\
\hline Segments & $165-190$ & $80-120$ & $135-140$ & $130-165$ \\
\hline Colour & $\begin{array}{lr}\text { Light brown with } \\
\text { purplish tingue } \\
\text { anterior side }\end{array}$ & Deep red & Purple pink & $\begin{array}{l}\text { Purple or reddish } \\
\text { brown }\end{array}$ \\
\hline Length & $10-21 \mathrm{~cm}$ & $5-11 \mathrm{~cm}$ & $8-15 \mathrm{~cm}$ & $10-15 \mathrm{~cm}$ \\
\hline
\end{tabular}


International Journal of Trend in Scientific Research and Development (IJTSRD) ISSN: 2456-6470

\begin{tabular}{|l|l|l|l|l|}
\hline Weight & $1.0-2.5 \mathrm{~g}$ & $0.9 \mathrm{mg}$ & $1.5-2.5 \mathrm{~g}$ & $1.7-2.0 \mathrm{~g}$ \\
\hline Feeders & Deep feeders $(10-30 \mathrm{~cm})$ & $\begin{array}{l}\text { Surface feeders } \\
(3-10 \mathrm{~cm})\end{array}$ & $\begin{array}{l}\text { Surface feeders }(3-10 \\
\mathrm{cm})\end{array}$ & $\begin{array}{l}\text { Surface feeders (3- } \\
10 \mathrm{~cm})\end{array}$ \\
\hline
\end{tabular}

\section{RESULT AND DISSCUSSION}

In the present study an attempt has been made to know the distribution and relative abundance of earthworms in Thiruppampuram village and dumping site from Kurikulam. The biodiversity of earthworms were analyzed related to their habitats considering species identification and richness of earthworm species in two different fields. Earthworm species were collected and identified generally according to their morphological characteristics, habitats and size. Four species such as Perionyx excavates, Eudrilus eugeniae, Eisenia foetida and Lampito maruitii were identified from paddy soil sites. Lampito maruitii, Perionyx excavates was the dominant species of paddy field and dumping site areas. The lowest abundant species were Eudrilus eugeniae and Eisenia foetida found in only paddy field.

Physico-Chemical parameters were analyzed the collected soils and soil texture was found Loamy and Silty soil. Different chemical parameters of the soil such as $\mathrm{pH}, \mathrm{N}, \mathrm{P}, \mathrm{K}$ (Macro nutrients) and $\mathrm{Fe}, \mathrm{Mn}$, $\mathrm{Zn}, \mathrm{Cu}$ (Micro nutrients) concentration was tested which was related to the abundance of loamy and silty soil. Highest earthworm abundance was recorded in paddy field. Where the soil was tested chemical conventions were good quality. On the other hand the lowest abundance of earthworms was observed in dumping site the soil was tested chemical conventions was low quality. The physicochemical, nutritional and biochemical parameters were observed in the soil were tested from ICAR institute of Aduthurai.

Earthworms are regarded as 'biological indicator' of soil fertility and a 'soil conditioner'. They lead to total improvement in the physical (soil porosity and softness), chemical (good $\mathrm{pH}$ and essential plant nutrients) and biological (beneficial soil microbes and organisms) quality of soil and land where they inhabit. They swallow large amount of soil with organics (microbes, plant and animal debris) everyday, grind them in their gizzard and digest them in their intestine with aid of enzymes. Only 5-10 percent of the chemically digested and ingested material is absorbed into the body and the rest is excreted out in the form of fine mucus coated granular aggregates called 'vermicastings' which are rich in NKP (nitrates, phosphates and potash), micronutrients and beneficial soil microbes (Scheu, 1987).

Table 2: Physico chemical parameters of two different sites in Thiruppampuram Village and Karikulam

\begin{tabular}{|c|c|c|c|c|c|}
\hline \multirow[b]{2}{*}{ SI. No } & \multirow[t]{2}{*}{ Parameter } & \multicolumn{2}{|c|}{ Thiruppampuram Village } & \multicolumn{2}{|c|}{ Karikulam } \\
\hline & & Silty soil & Loamy soil & Silty soil & Loamy soil \\
\hline 1. & $\mathrm{P}^{\mathrm{H}}$ & 74 & 72 & 80 & 81 \\
\hline 2. & $\mathrm{EC}(\mathrm{dSm}-1)$ & 0.16 & 0.08 & 1.9 & 0.13 \\
\hline 3. & Nitrogen $(\mathrm{N})(\%)$ & 60.2 & 70 & 50.8 & 61.6 \\
\hline 4. & Phosphorous (P) (\%) & 67.0 & 75 & 60 & 34.5 \\
\hline 5. & Potassium $(\mathrm{K})(\%)$ & 80 & 71.2 & 20 & 45 \\
\hline 6. & Iron (I) (ppm) & 7.0 & 7.3 & 6.0 & 6.4 \\
\hline 7. & $\begin{array}{l}\text { Manganes } \\
(\mathrm{ppm})\end{array}$ & 1.3 & 3.4 & 1.0 & 1.7 \\
\hline 8. & Zinc $(\mathrm{Zn})$ & 1.0 & 2.3 & 1.0 & 2.6 \\
\hline 9. & Cupper $(\mathrm{Cu})$ & 0.5 & 1.0 & - & 0.5 \\
\hline
\end{tabular}




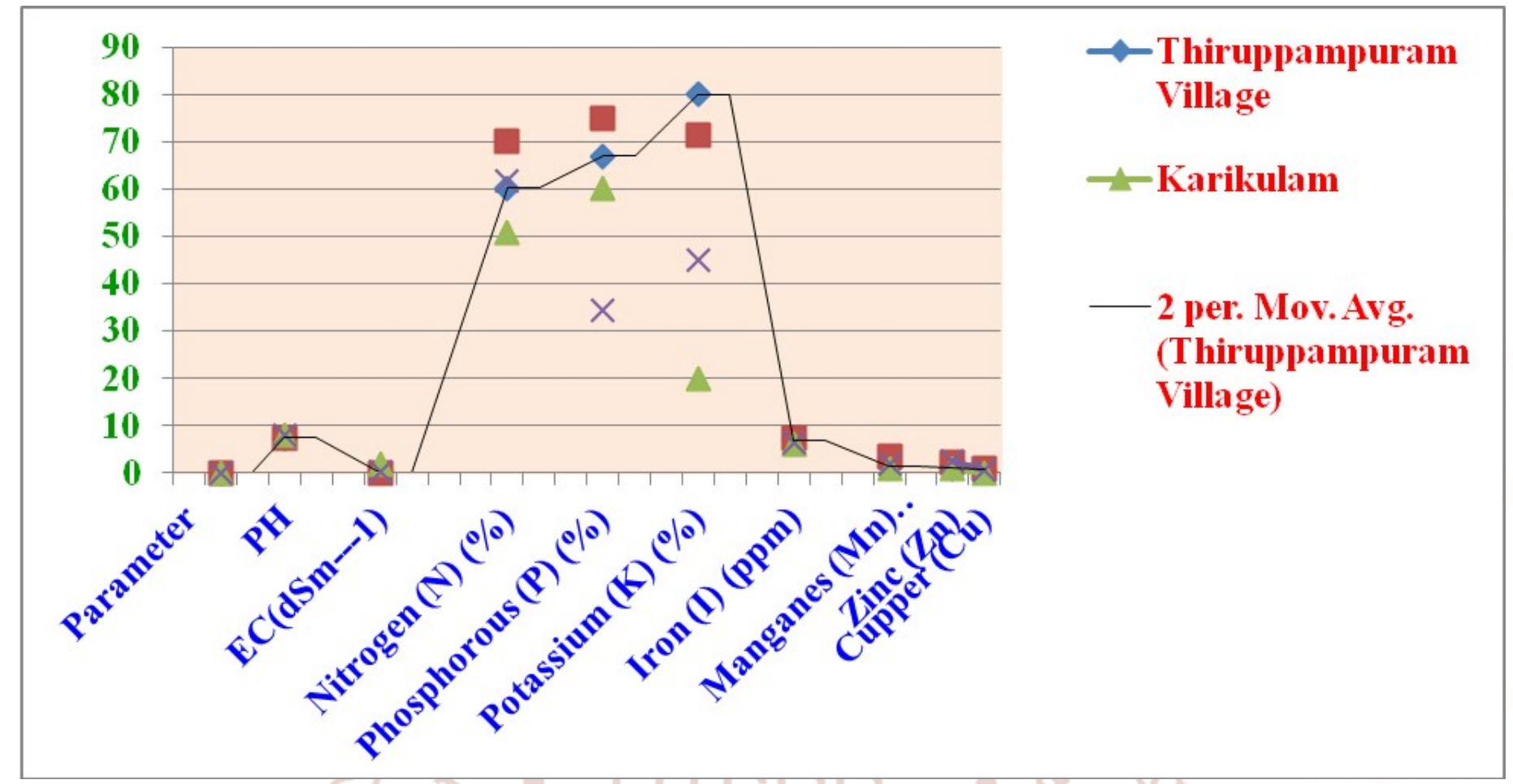

\section{CONCLUSION}

Present survey indicates the presence of four species of earthworms belonging to two different families of Lumbricidae, Megascolecidae in two different parts of Thiruppampuram village, and dumping site are of Kurikulam at Kumbakonam. The texture of soil has great influence on the distribution and population structure of earthworms is higher in paddy field at thiruppampuram village. Studies on different region of the globe and on different ecosystem have revealed that the earthworm diversity is highly variable owing to geographical region, climatic condition and disturbances in habitat concerned. The manipulation of natural habitat by anthropogenic activities has resulted into displacement of earthworm species.

\section{REFERENCES}

1. Bhat, J.V. and P.Khambata (1996). Role of earthworms in agriculture. Pub. of Indian Council of Agriculture Re-search (ICAR), 22, New Delhi, India, 36.

2. Bouche, M.B (1972). Lombriciens de France. Ecologie et Systematique (Paris: Institute National de la Recherches Agriculturelles.

3. Capowiez, Y., S. Cadoux., P. Bouchand., J. Roger-Estrade, G. Richard and H. Boizard (2009). Experimental evidence for the role of earthworms in compacted soil re-generation based on field observations and results from a semi-field experiment. Soil Biology \& Biochemistry, 41(4), 711-717.

4. Edwards, C.A. and E.F Neuhauser (1988). Earthworms in waste and Environmental Management. SPB Academic Press, The Hague, the Netherland.

5. Edwards, C.A. and J.P. Bohlen (1967). Biology and Ecology of Earthworms, 3 edn, Chapmann \& Hall.

6. Ismail, S.A., (2005). The Earthworm Book. Other India Press, Mapusa, Goa. 101p. Benedek P (1972) Possible indirect effect of weed control on population changes of wild bees pollinating lucerne. Acta Pathol Acad Sci Hung 7:267-278.

7. Julka, J.M. and B.K. Senapati (1987). Records of Zoological Survey of India: Earthworms (Oligochaeta: Annelida) of Orissa, India. Miscellaneous Publication (Occasional Paper No.92), Published by the Director, Zoological Survey of India, Calcutta.

8. Julka, J.M., (2001). Distribution of earthworms in different agro-climatic regions of India. Workshop on Tropical Soil Biology and fertility programme. School of Environmental Science, Jawaharlal Nehru University, New Delhi, p.1-12.

9. Julka,J.M. and R.Paliwal (1994). On a new species of Plutellus Perrier (Acanthodrilidae: 
Oligochaeta) from northwest Himalayas, India. Research Bulletin of the Punjab University (Science), 44:217-220.

10. Li, K.M. (2005). Vermiculture Industry in Circular Economy, Worm Digest. http://www.wormdigest.org/con tent/view/135/2/

11. Prakash,O., (2011). Evaluation of population density and diversity of earthworms in two agroecosystems in some regions of Uttar Pradesh with emphasis on solid waste management.Ph.D.Thesis submitted to Mahatma Jyotiba Phule Rohilkhand University, Bareilly (India).p.1-105.

12. Scheu, S. (1987). Microbial activity and nutrient dynamics in earthworms casts. Journal of Biological Fertility Soils, 5(3), 230-234.

13. Shuster, W.D., S. Subler and E.L. McCoy (2000). Foraging by deep-burrowing earthworms degrades surface soil structure of a fluventic hapludoll in Ohio. Soil and Tillage Research, 54: 179-189.

14. Stephenson, J. (1914). On a collection of Oligochaeta mainly from Northern India. Records of the Indian Museum, 10: 321-365.

15. Stephenson, J. (1923). The Fauna of British India including Ceylon and Burma. Oligochaeta. Taylor and Francis, London, 518pp+XXIV. 